\title{
Direct and indirect relationships between logging intensity and regeneration of two timber species in the Dry Chaco of Argentina
}

\author{
Andrés Tálamo ${ }^{\mathrm{a}, *}$, Javier Lopez de Casenave ${ }^{\mathrm{b}}$, Lucas A. Garibaldi ${ }^{\mathrm{c}, \mathrm{d}}$, Mauricio Núñez-Regueiro ${ }^{\mathrm{a}, \mathrm{e}}$ \\ ${ }^{a}$ Instituto de Bio y Geociencias del Noroeste Argentino (IBIGEO), Laboratorio de Ecología Aplicada a la Conservación (LEAC), Consejo de Investigaciones Científicas y \\ Técnicas (CONICET)-Universidad Nacional de Salta (UNSa), Avenida Bolivia 5150, 4400 Salta, Argentina \\ ${ }^{\mathrm{b}}$ Desert Community Ecology Research Team (Ecodes), Departamento de Ecología, Genética y Evolución, Facultad de Ciencias Exactas y Naturales, Universidad de Buenos \\ Aires, and IEGEBA (UBA-CONICET), Piso 4, Pabellón 2, Ciudad Universitaria, C1428EHA Buenos Aires, Argentina \\ ${ }^{\mathrm{c}}$ Universidad Nacional de Río Negro, Instituto de Investigaciones en Recursos Naturales, Agroecología y Desarrollo Rural, Río Negro, Argentina \\ ${ }^{\mathrm{d}}$ Consejo Nacional de Investigaciones Científicas y Técnicas, Instituto de Investigaciones en Recursos Naturales, Agroecología y Desarrollo Rural, Río Negro, Argentina \\ ${ }^{\mathrm{e}}$ Universidad Católica de Salta, Campus Castañares, 4400 Salta, Argentina
}

\section{A B S T R A C T}

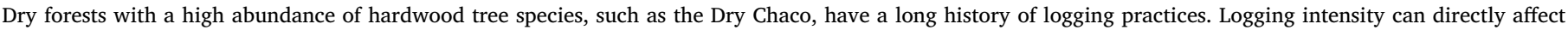

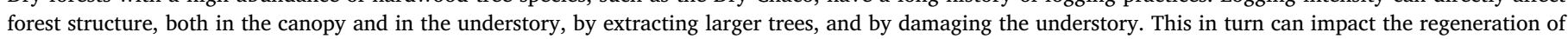

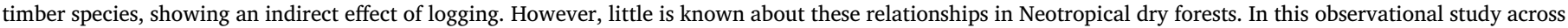

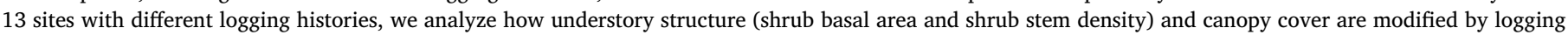

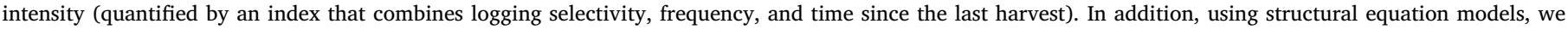

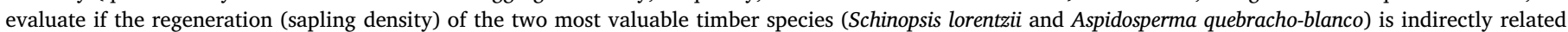

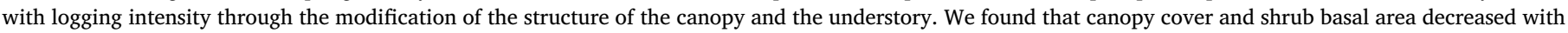

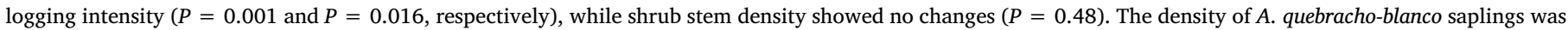

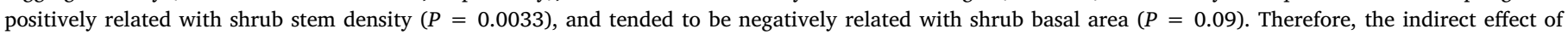

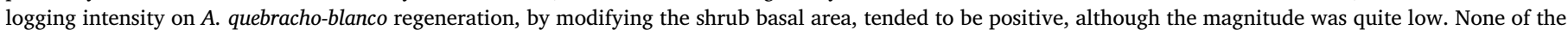

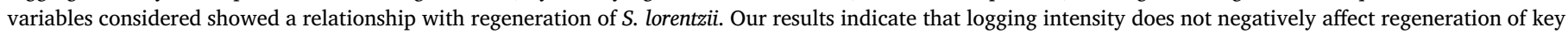

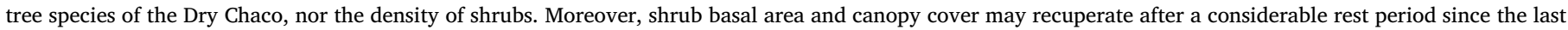

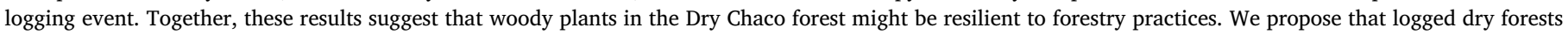

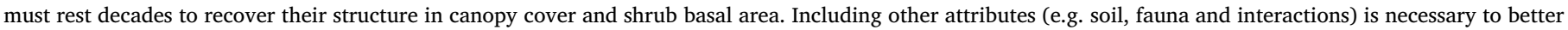
understand the possible influence of logging intensity on the ecological integrity and sustainability of dry woodlands like Chaco forests.

\section{Introduction}

Most rural communities throughout the world depend on incomes generated from timber and non-timber forest products (FAO, 2014), especially in dry forests (Blackie et al., 2014). Dry forests account for approximately half of the world's tropical and subtropical forests, and provide a livelihood for millions of people around the world. However, despite their importance, these forests are among the most threatened and least studied forest ecosystems in the world. As a result, assessing the ecological sustainability of logging in dry forests of all regions is an urgent research priority (Blackie et al., 2014). Different forest use practices can generate disturbances that can alter critical components and processes of a forest such as regeneration of timber species, abundance of shrubs and canopy structure, which are rarely considered together when assessing possible effects of logging. Moreover, it is likely that forestry practices will increase in the coming years because of the growing demand for forest products (FAO, 2014), which in turn will further endanger the already threatened dry forests. Therefore, in order to assess the sustainability of forestry, it is both urgent and necessary to generate information on the effects of logging on different components (e.g. understory structure and canopy openness) of dry forests.

The effects of logging on forest structure and regeneration depend on many factors, including harvest intensity and selectivity as well as extraction frequency. A very intense timber extraction (in terms of $\mathrm{m}^{3}$ $\mathrm{ha}^{-1}$ ), that is also non-selective (i.e., many target species) and with high extraction frequency, can generate a more open forest and increase soil compaction, affecting forest structure and plant regeneration

\footnotetext{
* Corresponding author.

E-mail addresses: andrestalamo@gmail.com (A. Tálamo), casenave@ege.fcen.uba.ar (J. Lopez de Casenave), lgaribaldi@unrn.edu.ar (L.A. Garibaldi), mnureg@yahoo.com (M. Núñez-Regueiro).
} 
(Zhirin and Knyazeva, 2012). These effects could be significantly reduced if logging is less intense or more selective or if it is done less frequently, as in the activities of reduced impact logging (Putz et al., 2008). In addition, time elapsed since the last logging event is another factor that may influence patterns of regeneration, albeit regeneration speed is still debated. Some studies show that in a few years of recovery, the composition of the herbaceous stratum resembles the original one (Costa and Magnusson, 2002), while others show that many decades are needed to restore forests to their original unlogged state (Lobo et al., 2007; Osazuwa-Peters et al., 2015). Knowing the forest use history of a site (i.e., the combination of selectivity, frequency and recovery time) is important for understanding the potential effects of logging on dry forest structure and the timber tree regeneration.

Logging can modify various forest components and processes. As a result of this, the sustainability of logging will depend on how these components and processes are impacted. Many studies aim to assess how the regeneration of timber species is affected by logging. However, the results are not consistent. Logging can enhance, decrease, or not affect forest regeneration depending on the characteristics of the logged species (e.g., early or late in succession, vegetative or sexual reproduction, shade intolerance) (Karsenty and Gourlet-Fleury, 2006; Nabe-Nielsen et al., 2007; Schwartz et al., 2012; Schwartz and Caro, 2003; Tálamo et al., 2013). In tropical and subtropical forests, logging often generates canopy openings and modifies the vertical structure, allowing more light into the forest, which in turn may promote the establishment and growth of shade-intolerant timber species (NabeNielsen et al., 2007; Win et al., 2012). In addition, the understory is an important component of forest ecosystem functionality because it contributes with important processes, such as forest regeneration, carbon storage, decomposition, nutrient flow, and buildup of soil nutrients (Caccia et al., 2009; Hou et al., 2015; Nilsson and Wardle, 2005; Royo and Carson, 2008). Shrubs can provide an important source of fruits for wildlife (Caziani and Protomastro, 1994; Ponce et al., 2012), or offer forage biomass for native and domestic herbivores (Bucher, 1987; Catan and Degano, 2007; Cora et al., 2005; Quiroga and Esnarriaga, 2014). Also, shrubs can promote regeneration niches that other plants can use for their establishment, growth and survival (Barchuk et al., 2005; Caccia et al., 2009; Tálamo et al., 2015a, 2015b; Trigo et al., 2017). Understanding how forestry affects understory vegetation structure and the regeneration of timber species is key to assess the sustainability of logging and measure potential consequences to ecosystem function.

The Dry Chaco forest in South America is characterized by a tree layer dominated by few yet valuable hardwood species (Morello and Adámoli, 1974) and a much dense and more diverse understory. The two species with the highest value for timber are white "quebracho" (Aspidosperma quebracho-blanco, Apocynaceae) and red "quebracho" (Schinopsis lorentzii, Anacardiaceae), both genera with heliophilous and long-lived pioneer species (Barberis et al., 2012; Mostacedo et al., 2009; Wenzel and Hampel, 1998, Tortorelli 2009). Because of the dominance of these tree species, for many decades this forest has been the target of a continuous and often indiscriminate timber extraction for the production of railroad ties, beams and charcoal (Bucher and Huszar, 1999; Morello et al., 2007; Kunst et al., 2014; Rueda et al., 2015). Currently, the Dry Chaco has the highest loss of woody vegetation in dry forests of Latin America and the Caribbean (Aide et al., 2013) and one of the highest in the world (Hansen et al., 2013). Although forest use is widespread in this environment, timber exploitation occurs without any spatial or temporal planning and without ensuring proper regeneration of major timber species (Brassiolo, 2001; Bucher and Huszar, 1999; Morello et al., 2007; Kunst et al., 2014). Moreover, empirical studies aimed at understanding the potential impact of logging on woody vegetation in the Chaco forest are scarce (Bonino and Araujo, 2005; Tálamo et al., 2013; Tálamo and Caziani, 2003). Large-scale studies that assess possible effects of logging in the Dry Chaco are essential for designing management plans that ensure the sustainability of forestry
(Ramage et al., 2013).

Here, we explore the possible effects of logging intensity (by considering logging selectivity, frequency and time since last harvest) on the shrub layer, canopy cover and timber tree regeneration. The features related to logging history were combined into an index of intensity of forest use. Specifically, we evaluated the relationship between this index and canopy cover, understory structure, and timber tree regeneration (sapling density). We propose a conceptual model to test the following working hypothesis: (1) logging intensity decrease canopy cover directly, by extracting larger trees, and (2) directly reduces the abundance and biomass of shrub stems, because timber extraction damages the understory and generates bare soil areas like gaps, trails, and roads (Tálamo et al., 2013). We consider that the physical damage to the understory is greater than the benefit that shrubs get from greater light availability. Finally, (3) logging intensity indirectly increases the density of saplings of the trees studied (since they are usually considered as heliophilous species) by diminishing canopy cover, and shrub stem density and biomass.

\section{Material and methods}

\subsection{Study site}

We conducted the study at Copo National Park $\left(25^{\circ} 55^{\prime} \mathrm{S}, 62^{\circ} 05^{\prime} \mathrm{W}\right)$ and adjacent areas, in the provinces of Santiago del Estero and Chaco, Argentina. Copo lies in the Semi-arid Chaco forest or Western Chaco Region (Prado, 1993), specifically in the Ancient Juramento Riverbeds Region (Morello et al., 2012). Rainfall and temperature are highly seasonal, with $80 \%$ of the $700 \mathrm{~mm}$ of annual rainfall concentrated in the spring-summer wet season (November to April) (Bianchi and Cravero, 2010). The dominant vegetation is a semi-deciduous thorn forest (Morello and Adámoli, 1974). The dominant tree species are Schinopsis lorentzii, Aspidosperma quebracho-blanco, and Ziziphus mistol (Rhamnaceae), which reach heights of 18-20 m. The dense understory is 1-6 m-tall and is dominated by Capparis retusa (Capparaceae), Acacia praecox (Fabaceae), Celtis pallida (Celtidaceae), Achatocarpus praecox (Achatocarpaceae), and Schinus polygamus (Anacardiaceae) (Tálamo and Caziani, 2003). The study area includes not only primary vegetation but also vegetation subjected to a variety of human disturbances. The most frequent disturbance is logging. Two types of logging are carried out in the study area: (1) removing only $S$. lorentzii individuals for posts, railroad ties and beams, locally referred to as selective logging, and (2) logging of all hardwood species (e.g., S. lorentzii, A. quebracho-blanco, Z. mistol, Caesalpinia paraguariensis (Fabaceae), Acacia furcatispina (Fabaceae)) for charcoal production, locally referred to as intense logging (hereafter non-selective logging). It is important to note that logging events occurred at different times in history, and with different frequency. For example, sites near the National Route $\mathrm{N}^{\circ} 16$ (which was historically used as a starting point for the forestry industry) were exploited first and more frequently than sites located further away from this route.

\subsection{Sampling design}

We selected 13 sites with different logging history (Fig. 1). After informally interviewing key land-owners, elderly members of the community, and forestry officials in Santiago del Estero province, we categorized each logged site into one of two discrete levels of "logging type" (i.e, either selectively or non-selectively exploited). Sites were also classified into one of two discrete categories of "recovery time" (recent logging: less than two years of recovery; and old logging: over ten years of recovery) and into one of two discrete categories of "logging frequency" (high: sites repeatedly logged in the last 10-15 years; or low: sites logged once). Eleven out of the 13 sites also had moderate livestock use. We combined and weighted these logging history features and built a Logging Intensity Index for each site. The resulting eight 


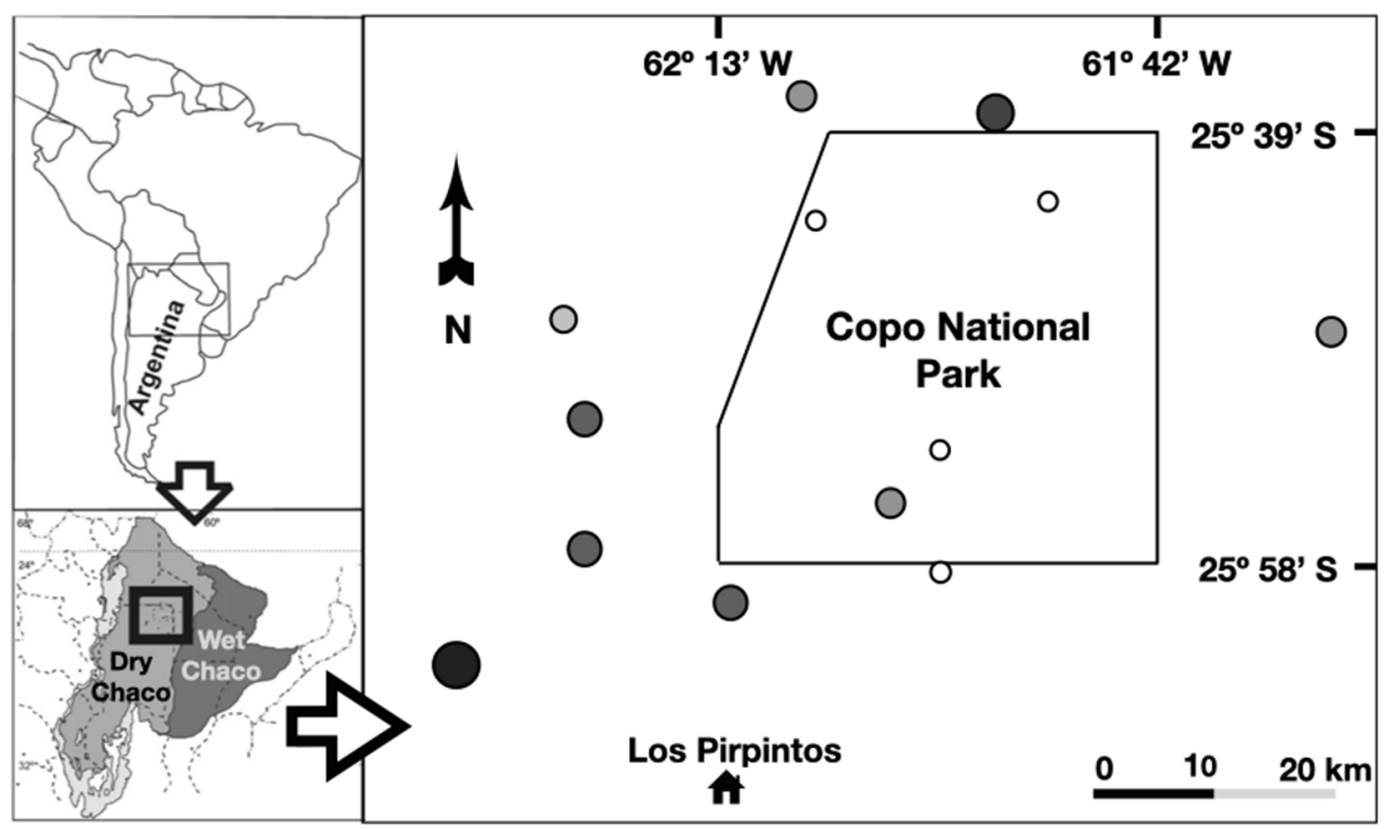

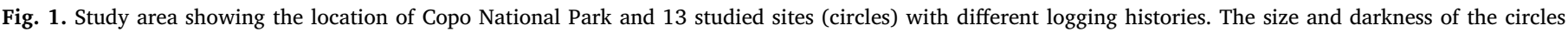

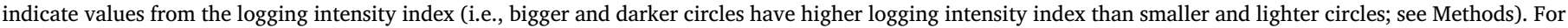

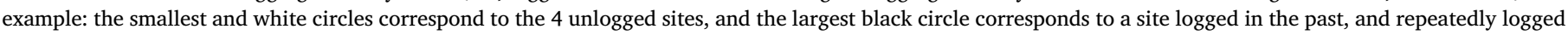
in recent years, at a high logging intensity.

combinations of logging type, frequency, and recovery time, were ordered in increasing logging intensity. At the lowest end of the intensity spectrum, we have an old, selective, and low-frequency logging. At the other end of the spectrum, we have recent, non-selective, and highfrequency logging. Between these two extremes, we ordered logging use history combinations as follows: (a) Old-selective-low frequency, (b) Old-selective-high frequency, (c) Old-non-selective-low frequency, (d) Old-non-selective-high frequency, (e) Recent-selective-low frequency, (f) Recent-selective-high frequency, (g) Recent-non-selective-low frequency, and (h) Recent-non-selective-high frequency. To reflect this order in the index, the ordered combinations had an increasing weighting factor, from 0.05 to 0.4 (with increments of 0.05). Each logged site was classified according to the presence (1) or absence (0) of the eight combinations of forest use history mentioned. Then the index was calculated as the sum of the presence (1) of each feature of the logging history (a-h mentioned above), multiplied by the corresponding weighting factor. The index varies from 0 to 1 . Zero (0) corresponds to an unlogged site, and one (1) to a site with high frequency of extraction that has been logged both selectively and non-selectively in the past and recently as well (Table S1).

On each site (approximately occupying 500-1000 ha) we randomly located 12 plots (except for one site where we placed 10 plots) spaced no less than $200 \mathrm{~m}$ apart, totaling 154 plots. Each plot was $2 \mathrm{~m}$ by $50 \mathrm{~m}$. On each plot we measured shrub diameter at a height of $10 \mathrm{~cm}$ on all branches greater than $0.5 \mathrm{~cm}$ in diameter, from which we calculated shrub basal area $\left(\mathrm{m}^{2} \mathrm{ha}^{-1}\right)$ and stem density (stems $100 \mathrm{~m}^{-2}$ ), and counted the number of saplings (individuals with diameter $<5 \mathrm{~cm}$ and height $<2 \mathrm{~m}$ ) of $A$. quebracho-blanco and $S$. lorentzii. On five points in each plot (spaced every $10 \mathrm{~m}$ ), we measured canopy cover with a spherical convex densiometer (except in one site). The analyzed variables were density of saplings of both timber species (saplings $100 \mathrm{~m}^{-2}$ ), basal area of shrubs $\left(\mathrm{m}^{2} \mathrm{ha}^{-1}\right)$, stem density of shrubs (stems $100 \mathrm{~m}^{-2}$ ), and canopy cover (\%).

\subsection{Data analysis}

We built generalized linear mixed-effects models to assess the relationship between logging intensity (i.e., a fixed effect) and each response variable related to forest structure (canopy cover, shrub basal area, and stem density) and to sapling density. Our models included sites as a random effect factor and plots nested within sites. We fitted linear and quadratic effects in our models, however, we report the results of linear models alone because quadratic models did not improve the model's performance as shown by the AIC (Akaike Information Criterion) (Table S2). Model residuals met the assumptions of normal distribution and homogeneity of variances. Statistical inference was accomplished with an analysis of variance (ANOVA).

The relationships among variables hypothesized in our conceptual model were tested using a Piecewise Structural Equation Modelling (SEM) approach (Lefcheck, 2016). Piecewise SEM allows fitting mixedeffects models to the paths of the hypothesized model and can account for the nested structure of our data (plots within sites). We estimated generalized linear mixed-effects models to assess the relationship between the variables present in different paths: canopy cover, shrub basal area, and stem density with logging intensity; and between $A$. quebracho-blanco and $S$. lorentzii regeneration with canopy cover, shrub basal area, and stem density. This approach allows us to infer direct and indirect effects of intensity of forest use on canopy cover, understory structure (basal area and stem density), and timber tree regeneration. To test the model fit of our SEM we used Shipley's test of d-separation (Shipley, 2009), and the model was regarded as fitted if $P>0.05$. All analyzes were performed in the $\mathrm{R}$ programming environment ( $\mathrm{R}$ Core Team, 2018), with the 'nlme' package (Pinheiro et al., 2015) and 'piecewiseSEM' package (Lefcheck, 2016).

\section{Results}

On the 154 plots that we measured (a total of $15,400 \mathrm{~m}^{2}$ ) we found 470 saplings of $A$. quebracho-blanco and 315 saplings of $S$. lorentzii. On average, we found 3.05 saplings of A. quebracho-blanco per $100 \mathrm{~m}^{2}$ (range $=0-17, \mathrm{sd}=2.94$ ) and 2.05 saplings of $S$. lorentzii per $100 \mathrm{~m}^{2}$ (range $=0-22$, sd $=2.95$ ). The mean density of saplings of $A$. quebracho-blanco per site varied from 1.67 saplings $100 \mathrm{~m}^{-2}$ (range $=0-3$, $\mathrm{sd}=1.07$ ) to 5.08 saplings $100 \mathrm{~m}^{-2}$ (range $=0-14$, $\mathrm{sd}=5.04$ ); for 
A)

\section{Aspidosperma quebracho-blanco}

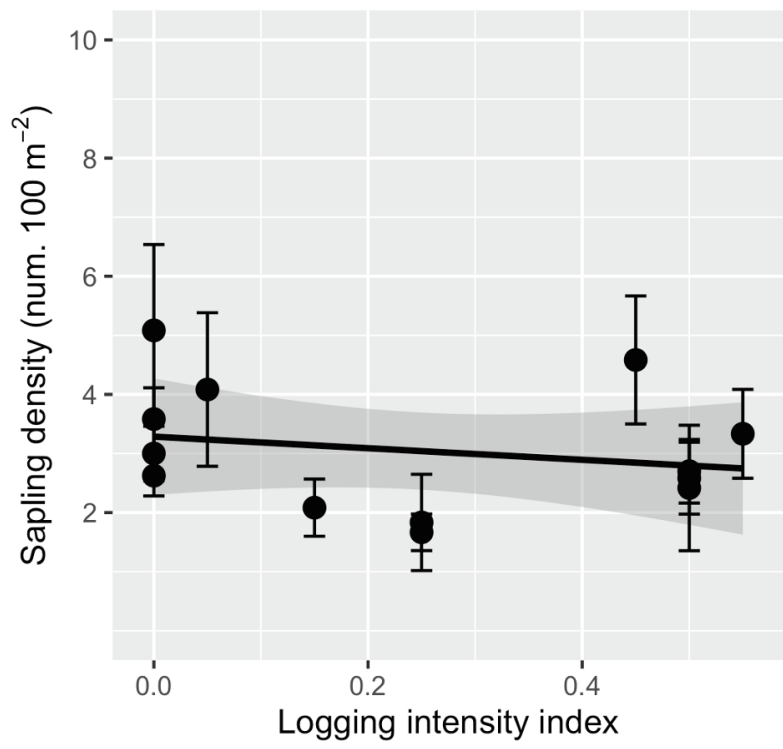

B)

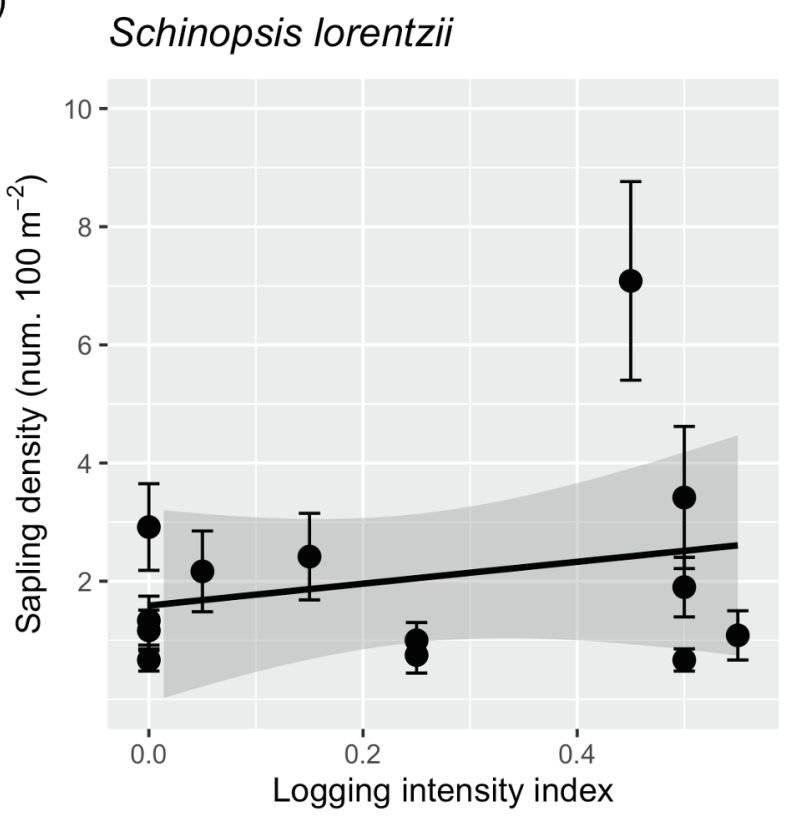

Fig. 2. Relationship between logging intensity index and sapling density of Aspidosperma quebracho-blanco (A), and Schinopsis lorentzii (B) in sites with different forest history in the Dry Chaco forest, Argentina. Means ( \pm SE), and $95 \%$ confidence bands are shown.

Schinopsis lorentzii, the mean density ranged from 0.67 saplings $100 \mathrm{~m}^{-2}$ (range $=0-2$, sd $=0.65$ ) to 7.08 saplings $100 \mathrm{~m}^{-2}$ (range $=3-22$, sd $=5.82$ ) (Fig. 2). The sapling density of A. quebrachoblanco and $S$. lorentzii was not related with logging intensity index $\left(\mathrm{b}_{\text {Asp.que }}=-0.64\right.$, se $=1.44, P=0.66 ; \mathrm{b}_{\text {Sch.lor }}=2.35$, se $=2.38$, $P=0.35$ ) (Fig. 2).

Canopy cover and shrub basal area were negatively related with logging intensity index $\left(\mathrm{b}_{\text {canopy_cover }}=-41.69\right.$, se $=9.20, P=0.0011$; $\mathrm{b}_{\text {basal_area }}=-6.57$, se $\left.=2.32, P=0.0164\right)$, whereas stem density did not vary with logging intensity $(\mathrm{b}=-29.78$, se $=40.71, P=0.48)$ (Fig. 3).

Our SEM adequately fitted the data (Fisher's $C=6.12 ; P=0.41$; $\mathrm{df}=6$ ) and had a high predictive power for all response variables
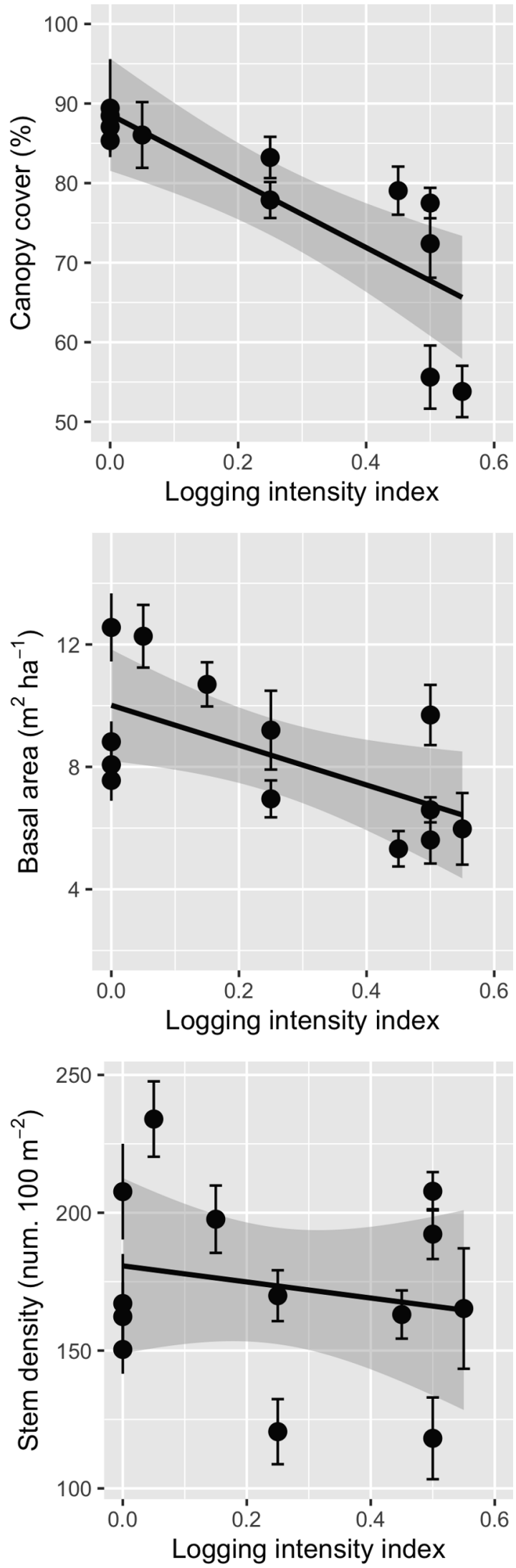

Fig. 3. Relationship between logging intensity index and canopy cover (A), shrub basal area (B), and shrub stem density (C), in sites with different forest history in the Dry Chaco forest, Argentina. Means ( \pm SE), and 95\% confidence bands are shown. Canopy cover was measured in 12 sites and all other variables were measured on all sites $(n=13)$. 


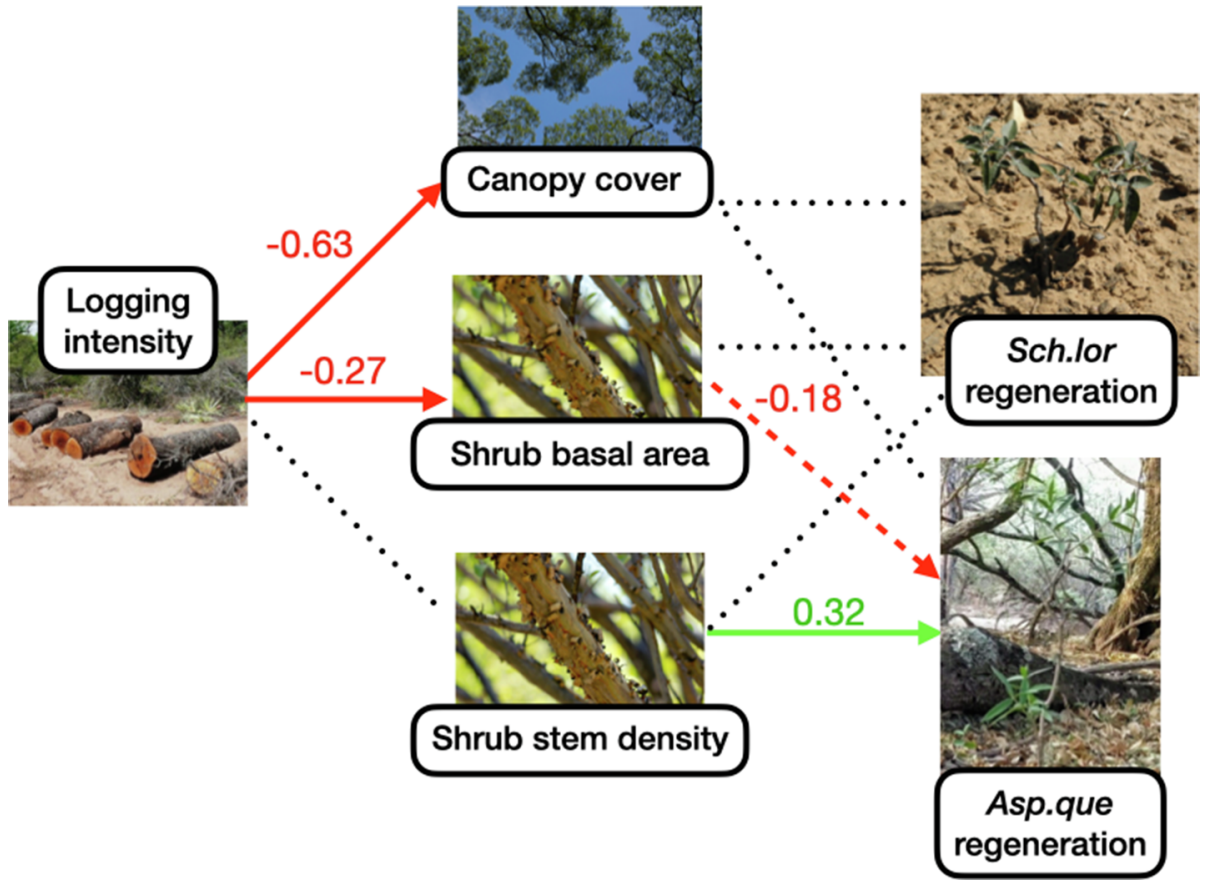

Fig. 4. Final path diagram showing the relationships among logging intensity, canopy cover, shrub basal area, shrub stem density and regeneration of the two timber species studied. Solid line arrows represent direct relationships between variables (paths) significant at the 0.05 level, each having a standardized coefficient [sign and colors indicates whether the relationship is positive (green) or negative (red) for that direct effect]. Red dashed line-arrows represent relationships marginally significant (0.05 $<P<0.10)$ and black dotted lines represent not significant relationships $(P>0.05)$. Coefficients can be compared to assess the relative importance of the variables. Asp.que: Aspidosperma quebracho-blanco; Sch.lor: Schinopsis lorentzii. (For interpretation of the references to colour in this figure legend, the reader is referred to the web version of this article.) (conditional $R^{2}$ values between 0.89 and 0.94). Canopy cover and shrub basal area were negatively related with logging intensity $(P=0.001$ and $P=0.053$, respectively), and A. quebracho-blanco regeneration was positively related with stem density $(P=0.003)$, and tended to be negatively related with shrub basal area $(P=0.09)$ (Fig. 4). Therefore, we observed a tendency for a positive indirect effect of logging intensity on A. quebracho-blanco regeneration mediated through shrub basal area (standardized indirect effect coefficient: $-0.27 \times-0.18=0.05$ ). Finally, we did not find any indirect effect (i.e. mediated by canopy cover, shrub basal area or stem density) of logging intensity on S. lorentzii regeneration.

\section{Discussion}

Logging practices can have different effects on several forest attributes like regeneration and forest structure (Bonino and Araujo, 2005; Karsenty and Gourlet-Fleury, 2006; Osazuwa-Peters et al., 2015; Schwartz et al., 2012; Schwartz and Caro, 2003; Win et al., 2012). However, the potential indirect effects of logging on the regeneration of timber species through the modification of forest structure is an aspect that is often overlooked when evaluating the ecological sustainability of logging. Here, we found that increasing timber extraction intensity and frequency (i.e. a higher logging intensity index) result in a forest with a more open canopy and understory, with lower biomass in terms of shrub basal area. However, this change in forest structure did not seem to substantially affect the density of saplings of the two timber species in our study site.

\subsection{Direct effects of logging intensity on forest structure}

Forest structure is the first attribute affected by logging. Timber extraction, by removing big trees, generates gaps, creating a more open canopy and affecting the understory. In our study, both canopy cover and basal area of shrubs were negatively related with the logging intensity index. The main species harvested, A. quebracho-blanco and $S$. lorentzii, are the biggest and most dominant species that compose the canopy. At higher intensity and frequency of extraction, the damage caused to the understory is greater and more open spaces are generated through main roads, skid trails, and logging gaps (Fredericksen and Pariona, 2002; Tálamo et al., 2013). Understandably, vegetation cover, both in the understory and in the overstory, is lower because study plots include areas affected by roads, trails, and gaps. Although logging could have a positive effect on the shrub layer by generating more open sites and increasing light availability (Lopez de Casenave et al., 1995), we hypothesized that the net effect is negative because the effect caused by the physical damage of the understory outweighs the positive one. Nevertheless, the fact that old logged sites had a canopy cover and basal area higher than recently logged sites, and similar to unlogged forests (Fig. S1), suggests that the structure of the forest can be recovered in decades. Thus, a forest recently logged non-selectively could recover its structure if enough time elapses. Similar results have been found for logged forests with long recovery periods (Nabe-Nielsen et al., 2007). The understory vegetation in seasonal dry forests (such as the Dry Chaco) is an important component because it represents a large percentage of basal area, as well as greatly contributes to the density and diversity of woody species (Tálamo et al., 2012). Consequently, assessing the extent to which the structure of the understory is affected by logging intensity is critical.

\subsection{Indirect effects of logging intensity on timber tree regeneration}

The changes in canopy cover and understory basal area generated by logging are related with the amount of light that reaches the understory, thus influencing the regeneration patterns in forests (Lobo et al., 2007; Nabe-Nielsen et al., 2007; Tálamo et al., 2013). The way in which timber species respond to forestry practices may be related to life history traits, such as their dependence on light for establishment. Shade-intolerant species may be favored by logging if the removal of large trees generates gaps that allow higher light levels on lower strata, which can promote germination of their seeds and growth of seedlings. Species of the genera Aspidosperma and Schinopsis have been classified as long-lived pioneers but partially shade-tolerant (Barberis et al., 2012; Mostacedo et al., 2009; Wenzel and Hampel, 1998), and the species studied (A. quebracho-blanco and $S$. lorentzii) have been considered as shade-intolerant species (Tortorelli 2009), and therefore would require some direct sunlight to establish and grow.

We predicted that with higher intensity of forest use, the density of saplings of both tree species would also be higher because of a greater sunlight exposure in comparison with sites with lower intensity of use. While canopy cover and shrub basal area decreased with higher levels 
of intensity of forest use, we found no strong evidence to support the idea of an indirect effect of logging on regeneration. Only the regeneration of $A$. quebracho-blanco had a tendency to increase indirectly with the intensity of use, although the magnitude of this effect was very low and not statistically significant. Neither does our data support the idea that both of the studied timber species are truly shade-intolerant species, and therefore depend on direct sunlight to establish and grow. Our results are supported by a study carried out in another fragmented Chaco forest, where both A. quebracho-blanco and a congeneric species of $S$. lorentzii might also be capable of regenerating under the canopy of the forest (Torrella et al., 2015). Manipulative controlled studies might confirm the trends reported in this study and help advance our understanding regarding the causal relationship between natural regeneration and sunlight.

\subsection{Conclusions}

We report the first study that assesses the relationships between different logging intensities and the structure of the canopy, the structure of the understory, and the regeneration of timber species in the Dry Chaco at a subregional scale. In conclusion, we did not detect effects of logging intensity on the regeneration of the two main timber species. Furthermore, we propose that the negative effects of logging on canopy cover and on shrub basal area can be overturned if the forest is left to rest for a considerable time (a decade, at least). Similarly, earlier studies showed that the specific composition of the woody plant community was not related to forest use at the stand scale (Tálamo et al., 2012), and that the regeneration of $S$. lorentzii and A. quebracho-blanco and the composition of the woody plant community does not depend on the microsite conditions generated by logging (Tálamo et al., 2013). Together, these results suggest that the community of woody plants in the Dry Chaco forest might be resilient to traditional land uses in general, and to forestry practices in particular. Notwithstanding, we should take into account other attributes (e.g. soil, fauna, and its ecological interactions) to evaluate the ecological sustainability of logging in the threatened Chaco forests.

\section{CRediT authorship contribution statement}

Andrés Tálamo: Conceptualization, Methodology, Formal analysis, Investigation, Resources, Writing - original draft, Writing - review \& editing, Visualization, Funding acquisition. Javier Lopez de Casenave: Writing - original draft, Writing - review \& editing. Lucas A. Garibaldi: Conceptualization, Formal analysis, Writing - review \& editing. Mauricio Núñez-Regueiro: Writing - original draft, Writing - review \& editing.

\section{Declaration of Competing Interest}

The authors declare that they have no known competing financial interests or personal relationships that could have appeared to influence the work reported in this paper.

\section{Acknowledgements}

This work was supported by the Research Council of the Universidad Nacional de Salta (grant 1477, 997 and Project 752), and the Rufford Foundation. We thank the local inhabitants and park staff of Parque Nacional Copo for their support during our fieldwork. We also thank Ignacio Barberis, who contributed with the discussion about the use of piecewise SEM. We especially thank two anonymous reviewers for providing valuable comments on this manuscript.

\section{Appendix A. Supplementary material}

Supplementary data to this article can be found online at https:// doi.org/10.1016/j.foreco.2020.118343.

\section{References}

Aide, T.M., Clark, M.L., Grau, H.R., Lopez-Carr, D., Levy, M.A., Redo, D., Bonilla-Moheno, M., Riner, G., Andrade-Nunez, M.J., Muniz, M., 2013. Deforestation and reforestation of Latin America and the Caribbean (2001-2010). Biotropica 45, 262-271. https:// doi.org/10.1111/j.1744-7429.2012.00908.x.

Barberis, I.M., Mogni, V., Oakley, L., Alzugaray, C., Vesprini, J.L., Prado, D.E., 2012. Biología de especies australes: Schinopsis balansae Engl. (Anacardiaceae). Kurtziana $37,59-86$.

Barchuk, A.H., Valiente-Banuet, A., Diaz, M.P., 2005. Effect of shrubs and seasonal variability of rainfall on the establishment of Aspidosperma quebracho-blanco in two edaphically contrasting environments. Austral Ecol. 30, 695-705. https://doi.org/10. 1111/j.1442-9993.2005.01511.x.

Bianchi, A., Cravero, S., 2010. Atlas climático digital de la República Argentina. Instituto Nacional de Tecnología Agropecuaria, Buenos Aires.

Blackie, R., Baldauf, C., Gautier, D., Gumbo, D., Kassa, H., Parthasarathy, N., Paumgarten, F., Sola, P., Pulla, S., Waeber, P., Sunderland, T.C.H., 2014. Tropical dry forests: The state of global knowledge and recommendations for future research (CIFOR discussion paper No. 2). Center for International Forestry Research, Bogor, Indonesia.

Bonino, E.E., Araujo, P., 2005. Structural differences between a primary and a secondary forest in the Argentine Dry Chaco and management implications. For. Ecol. Manage. 206, 407-412. https://doi.org/10.1016/j.foreco.2004.11.009.

Brassiolo, M., 2001. Los bosques del Chaco Semiárido. Propuestas para la conservación de bosques degradados. IDIA 21, 23-28.

Bucher, E.H., 1987. Herbivory in arid and semi-arid regions of Argentina. Rev. Chil. Hist. Nat. 60, 265-273.

Bucher, E.H., Huszar, P.C., 1999. Sustainable management of the Gran Chaco of South America: ecological promise and economic constraints. J. Environ. Manage. 57, 99-108.

Caccia, F.D., Chaneton, E.J., Kitzberger, T., 2009. Direct and indirect effects of understorey bamboo shape tree regeneration niches in a mixed temperate forest. Oecologia 161, 771-780. https://doi.org/10.1007/s00442-009-1412-z.

Catan, A., Degano, C.A.M., 2007. Composición botánica de la dieta de caprinos en un bosque del Chaco semiárido (Argentina). Quebracho 14, 15-22.

Caziani, S.M., Protomastro, J.J., 1994. Diet of the Chaco-chachalaca. Wilson Bulletin 106, 640-648.

Cora, A., Bregaglio, M.N., Coirini, R., 2005. Goat preferences for native woody shrubs in the Chaco Árido region of Córdoba, Argentina. Spanish J. Agric. Res. 3, 243-247.

Costa, F., Magnusson, W., 2002. Selective logging effects on abundance, diversity, and composition of tropical understory herbs. Ecol. Appl. 12, 807-819. https://doi.org/ $10.2307 / 3060991$.

FAO, 2014. State of the world's forests. Enhancing the socioeconomic benefits from forests. Food and Agriculture Organization of the United Nations, Roma.

Fredericksen, T.S., Pariona, W., 2002. Effect of skidder disturbance on commercial tree regeneration in logging gaps in a Bolivian tropical forest. For. Ecol. Manage. 171, 223-230. https://doi.org/10.1016/S0378-1127(01)00767-8.

Hansen, M.C., Potapov, P.V., Moore, R., Hancher, M., Turubanova, S.A., Tyukavina, A., Thau, D., Stehman, S.V., Goetz, S.J., Loveland, T.R., Kommareddy, A., Egorov, A., Chini, L., Justice, C.O., Townshend, J.R.G., 2013. High-resolution global maps of 21st-century forest cover change. Science 342, 850-853. https://doi.org/10.1126/ science. 1244693.

Hou, L., Xi, W., Zhang, S., 2015. Effect of understory on a natural secondary forest ecosystem carbon budget. Russian J. Ecol. 46, 51-58. https://doi.org/10.1134/ s1067413615010099.

Karsenty, A., Gourlet-Fleury, S., 2006. Assessing sustainability of logging practices in the Congo Basin's managed forests: The issue of commercial species recovery. Ecol. Soc. 11.

Kunst, C., Bravo, S., Ledesma, R., Navall, M., Anríquez, A., Coria, D., Silberman, J., Gómez, A., Albanesi, A., 2014. Ecology and management of the dry forests and savannas of the western Chaco region, Argentina, in: Greer, F.E. (Ed.), Dry Forests: Ecology, Species Diversity and Sustainable Management. p. 189.

Lefcheck, J.S., 2016. PIECEWISESEM: Piecewise structural equation modelling in R for ecology, evolution, and systematics. Methods Ecol. Evol. 7, 573-579. https://doi.org/ 10.1111/2041-210X.12512.

Lobo, J., Barrantes, G., Castillo, M., Quesada, R., Maldonado, T., Fuchs, E.J., Solis, S., Quesada, M., 2007. Effects of selective logging on the abundance, regeneration and short-term survival of Caryocar costaricense (Caryocaceae) and Peltogyne purpurea (Caesalpinaceae), two endemic timber species of southern Central America. For. Ecol. Manage. 245, 88-95. https://doi.org/10.1016/j.foreco.2007.03.067.

Lopez de Casenave, J., Pelotto, J.P., Protomastro, J., 1995. Edge-interior differences in vegetation structure and composition in a Chaco semi-arid forest, Argentina. For. Ecol. Manage. 72, 61-69.

Morello, J., Adámoli, J., 1974. Las grandes unidades de vegetación y ambiente del Chaco argentino. Segunda parte: vegetación y ambiente de la Provincia del Chaco. Instituto Nacional de Tecnología Agropecuaria, Buenos Aires.

Morello, J., Pengue W., Rodríguez A.F., 2007. Un siglo de cambios de diseño del paisaje: el Chaco Argentino. S.D. Matteucci (Ed.), Panorama de la Ecología de Paisajes en Argentina y Países Sudamericanos. Ediciones INTA, Buenos Aires.

Morello, J., Matteucci, S.D., Rodríguez, A.F., Silva, M.E., 2012. Ecorregiones y Complejos 
Ecosistémicos Argentinos. Orientación Gráfica Editora, Buenos Aires.

Mostacedo, B., Putz, F.E., Fredericksen, T.S., Villca, A., Palacios, T., 2009. Contributions of root and stump sprouts to natural regeneration of a logged tropical dry forest in Bolivia. For. Ecol. Manage. 258, 978-985. https://doi.org/10.1016/j.foreco.2008.09. 059.

Nabe-Nielsen, J., Severiche, W., Fredericksen, T., Nabe-Nielsen, L.I., 2007. Timber tree regeneration along abandoned logging roads in a tropical Bolivian forest. New Forest. 34, 31-40. https://doi.org/10.1007/s11056-006-9035-2.

Nilsson, M.C., Wardle, D.A., 2005. Understory vegetation as a forest ecosystem driver: evidence from the northern Swedish boreal forest. Front. Ecol. Environ. 3, 421-428. https://doi.org/10.1890/1540-9295(2005)003[0421:uvaafe]2.0.co;2.

Osazuwa-Peters, O.L., Chapman, C.A., Zanne, A.E., 2015. Selective logging: does the imprint remain on tree structure and composition after 45 years? Conserv. Physiol. 3 , cov012. https://doi.org/10.1093/conphys/cov012.

Pinheiro, J., Bates, D., DebRoy, S., Sarkar, D., 2015. nlme: linear and nonlinear mixed effects models.

Ponce, A.M., Grilli, G., Galetto, L., 2012. Frugivoría y remoción de frutos ornitócoros en fragmentos del bosque chaqueño de Córdoba (Argentina). Bosque 33, 7-8. https:// doi.org/10.4067/S0717-92002012000100004.

Prado, D.E., 1993. What is the Gran Chaco vegetation in South America? II. A redefinition. Contribution to the study of the flora and vegetation of the Chaco. VII. Candollea 48, 615-629.

Putz, F.E., Sist, P., Fredericksen, T., Dykstra, D., 2008. Reduced-impact logging: Challenges and opportunities. For. Ecol. Manage. 256, 1427-1433. https://doi.org/ 10.1016/j.foreco.2008.03.036.

Quiroga, A., Esnarriaga, D., 2014. Diversidad de forrajeras nativas consumidas por el ganado caprino en el área pedemontana del Chaco árido, Catamarca. Biología en Agronomía 4, 121-147.

$\mathrm{R}$ Core Team, 2018. R: A language and environment for statistical computing. $\mathrm{R}$ Foundation for Statistical Computing, Vienna.

Ramage, B.S., Sheil, D., Salim, H.M.W., Fletcher, C., Mustafa, N.-Z.-A., Luruthusamay, J.C., Harrison, R.D., Butod, E., Dzulkiply, A.D., Kassim, A.R., Potts, M.D., 2013. Pseudoreplication in tropical forests and the resulting effects on biodiversity conservation. Conserv. Biol. 27, 364-372. https://doi.org/10.1111/cobi.12004.

Royo, A.A., Carson, W.P., 2008. Direct and indirect effects of a dense understory on tree seedling recruitment in temperate forests: habitat-mediated predation versus competition. Can. J. For. Res. 38, 1634-1645. https://doi.org/10.1139/x07-247.

Rueda, C.V., Baldi, G., Gasparri, I., Jobbágy, E.G., 2015. Charcoal production in the Argentine Dry Chaco: Where, how and who? Energy Sustain. Dev. 27, 46-53. https:// doi.org/10.1016/j.esd.2015.04.006.

Schwartz, G., Pena-Claros, M., Lopes, J.C.A., Mohren, G.M.J., Kanashiro, M., 2012. Midterm effects of reduced-impact logging on the regeneration of seven tree commercial species in the Eastern Amazon. For. Ecol. Manage. 274, 116-125. https://doi.org/10. 1016/j.foreco.2012.02.028

Schwartz, M.W., Caro, T.M., 2003. Effect of selective logging on tree and understory regeneration in miombo woodland in western Tanzania. Afr. J. Ecol. 41, 75-82. https://doi.org/10.1046/j.1365-2028.2003.00417.x.

Shipley, B., 2009. Confirmatory path analysis in a generalized multilevel context. Ecology 90, 363-368. https://doi.org/10.1890/08-1034.1.

Tálamo, A., Barchuk, A., Cardozo, S., Trucco, C., Marás, G., Trigo, C., 2015a. Direct versus indirect facilitation (herbivore mediated) among woody plants in a semiarid Chaco forest: A spatial association approach. Austral Ecol. 40, 573-580. https://doi.org/10. 1111/aec.12224.

Tálamo, A., Barchuk, A.H., Garibaldi, L.A., Trucco, C.E., Cardozo, S., Mohr, F., 2015b. Disentangling the effects of shrubs and herbivores on tree regeneration in a dry Chaco forest (Argentina). Oecologia 178, 847-854. https://doi.org/10.1007/s00442-0153269-7.

Tálamo, A., Caziani, S.M., 2003. Variation in woody vegetation among sites with different disturbance histories in the Argentine Chaco. For. Ecol. Manage. 184, 79-92. https:// doi.org/10.1016/S0378-1127(03)00150-6.

Tálamo, A., Lopez de Casenave, J., Caziani, S.M., 2012. Components of woody plant diversity in semi-arid Chaco forests with heterogeneous land use and disturbance histories. J. Arid Environ. 85, 79-85. https://doi.org/10.1016/j.jaridenv.2012.05.008.

Tálamo, A., Lopez de Casenave, J., Núñez-Regueiro, M., Caziani, S.M., 2013. Regeneración de plantas leñosas en el Chaco semiárido argentino: relación con factores bióticos y abióticos en micrositios creados por el aprovechamiento forestal. Bosque 34, 53-62. https://doi.org/10.4067/S0717-92002013000100007.

Torrella, S.A., Ginzburg, R., Galetto, L., 2015. Forest fragmentation in the Argentine Chaco: recruitment and population patterns of dominant tree species. Plant Ecol. 216, 1499-1510.

Tortorelli, L.A., 2009. Maderas y Bosques Argentinos, second ed. Orientación Gráfica Editora, Buenos Aires.

Trigo, C.B., Tálamo, A., Núñez-Regueiro, M.M., Derlindati, E.J., Marás, G.A., Barchuk, A.H., Palavecino, A., 2017. A woody plant community and tree-cacti associations change with distance to a water source in a dry Chaco forest of Argentina. Rangeland J. 39, 15-23. https://doi.org/10.1071/RJ16014.

Wenzel, M., Hampel, H., 1998. Regeneración de las principales especies arbóreas del Chaco Húmedo argentino. Quebracho 6, 5-18.

Win, R.N., Suzuki, R., Takeda, S., 2012. Effects of selective logging on the regeneration of two commercial tree species in the Kabaung reserved forest, Bago mountains, Myanmar. J. Trop. For. Sci. 24, 312-321.

Zhirin, V.M., Knyazeva, S.V., 2012. Changes in the forest cover after intense logging in southern taiga of the Russian Federation. Contemp. Probl. Ecol. 5, 669-676. https:// doi.org/10.1134/s1995425512070104. 